\title{
The Importance of Internal Resources and Capabilities and Destination Resources to Explain Firm Competitive Position in the Spanish Tourism Industry
}

\author{
CÉSAR CAMISÓN ${ }^{1}$ ALBA PUIG-DENIA ${ }^{2 *}$ BEATRIZ FORÉS ${ }^{2}$ MARÍA EUGENIA FABRA ${ }^{3}$ AZAHARA MUÑOZ ${ }^{4}$ \\ and CÉSAR MUÑOZ MARTÍNEZ ${ }^{5}$ \\ ${ }^{1}$ Universitat de València, Facultad de Economía, Departamento de Dirección de Empresas, Av. dels Tarongers s/n, 46022 Valencia, Spain \\ ${ }^{2}$ Universitat Jaume I, Facultad de Ciencias Jurídicas y Económicas, Departamento de Administración de Empresas y Marketing, Av. Vicent \\ Sos Baynat s/n, 12071 Castellón, Spain \\ ${ }^{3}$ Universidad Pontificia de Comillas—ICADE, Facultad de Ciencias Económicas y Empresariales, Departamento de Métodos Cuantitativos, \\ C. Alberto Aguilera 23, 28015 Madrid, Spain \\ ${ }^{4}$ ESIC Business \& Marketing School, Av. Valdenigrales s/n, 28223 Pozuelo de Alarcón, Madrid, Spain \\ ${ }^{5}$ Universidad Nacional de Educación a Distancia-UNED, Facultad de Ciencias Económicas y Empresariales, Paseo Senda del Rey 11, \\ 28040 Madrid, Spain
}

\begin{abstract}
This study draws on the Resource-Based View to analyze the effects of distinctive competences in tourism firms and location in a tourism district on competitive position, and explores the moderating effects of the tourism destination. Multiple linear regression was used to test the research hypotheses on a sample of 1019 Spanish tourism firms. Results reveal that financial resources and dynamic and production capabilities favor a better competitive position for tourism firms in general; however, coordination and marketing capabilities are key factors for firms embedded in a tourism district, while dynamic capabilities have a negative effect in this case. Copyright (C) 2015 John Wiley \& Sons, Ltd.
\end{abstract}

Received 1 August 2014; Revised 4 March 2015; Accepted 25 April 2015

KEY WORDS distinctive competences; tourism destination; competitiveness; tourism sector

\section{INTRODUCTION}

The competitiveness of a tourism firm depends on a wide range of factors internal and external to the organization (Enright \& Newton, 2004). The literature has classified the causal effects of firm results into three groups (Porter, 1990; Rumelt, 1984): country advantages (based on comparative advantages), industry advantages (deriving from the attractiveness of the market structure) and firm advantages (based on the characteristics of the firm itself). Although these three groups include numerous factors, two aspects are particularly relevant in the case of the tourism firm: the resources and capabilities of each firm, and the destination where the organization is located. A tourism firm's success is based on its capability to provide positive experiences (Crouch \& Ritchie, 1999), which depends on the business and service systems available in the firm itself, but also on the elements found within the destination, such as the quality of its natural resources, hospitality, security, cleanliness, cultural attractions, etc.

The Resource-Based View (RBV) highlights the resources and capabilities belonging to each firm, and anticipates that there will be notable and persistent differences in intraindustry and intra-country competitive success due to the

* Correspondence to: Alba Puig-Denia, Universitat Jaume I, Facultad de Ciencias Jurídicas y Económicas, Departamento de Administración de Empresas y Marketing, Av. Vicent Sos Baynat, s/n, 12071 Castellón, Spain. E-mail: puiga@uji.es specific factors of each organization; these differences will be even greater than intra-industrial or international divergences (Mauri \& Michaels, 1998; Rumelt, 1991; Hansen \& Wernerfelt, 1989). According to this view, the competitive success or failure of a tourism firm will essentially depend on its resources and capabilities, and to a lesser extent on the destination in which it is located.

In addition, it is widely acknowledged that the tourism product is an integrated product (Vogt \& Fesenmaier, 1995; Smith, 1994). The tourist perceives each destination as a product with a set of attributes that interrelate and combine to shape a whole, complete experience of the visited area (Murphy, Pritchard, \& Smith, 2000). The destination in which tourism firms are located therefore has a major influence on their competitiveness (Dwyer et al., 2009; Gomezelj $\&$ Mihalič, 2008). In this vein, the term district or cluster becomes significant as a useful model to explain the reasons and the operational dynamics of established tourism destinations. This idea was encapsulated by Molteni and Sainaghi (1997) when they first coined the term 'tourism district'.

The classic perspective in the study of external effectssuch as the industry and country effect—and internal firm effects-mainly derived from its strategic position and its distinctive resources and capabilities - on firm competitiveness is based on the analysis and treatment of these effects as independent (e.g. Spanos, Zaralis, \& Lioukas, 2004; Rothaermel, 2001; Brush \& Bromiley, 1997; Rumelt, 1991; Schmalensee, 1985). However, some conceptual studies 
have noted that these external and internal effects are not independent; rather, they are complementary effects (e.g. Goll, Brown Johnson, \& Rasheed, 2007; Hill \& Deeds, 1996; Porter, 1991). Understanding the complementarity between the internal assets that the firm controls, and the external assets it can access in its immediate environment is an important point both for the literature and for managerial practice. It is important to the literature because it opens up the way to integrate lines of research that, to date, have been mutually unfamiliar - such as the theory of resources and capabilities, and the theory of industrial districts-despite the growing evidence of flows in both directions between the firm and its immediate environment. On a practical level it is important because it can provide managers with empirically validated conclusions on the potential value creation deriving from combining internal and external resources and capabilities, and suggest ways of managing this integration to optimize the strategic value of both types of assets.

The present study continues in this line, and our contribution adds to previous research (Camisón \& Forés, 2011; Molina-Azorin, Pereira-Moliner, \& Claver-Cortés, 2010; Camisón, 2004) that has also studied tourism firm competitiveness from the perspective of its location and internal characteristics, providing evidence that both effects influence firm performance. Our contribution to the state-of-the-art lies in its specific analysis of the effect of location in a tourism district, and the access to the resources available in these immediate geographical surroundings, on each one of the firm's main groups of capabilities - dynamic capabilities, coordination and cohesion capabilities, functional marketing and production capabilities - and its physical and financial resources. The conclusions drawn from the empirical study guide managers on how to direct the absorption of the district's resources, knowledge flows, information, experience and capabilities in order to exploit their own resources and capabilities with the aim of creating a superior competitive position.

In the next section we review the existing theory on the destination effect and the firm effect on competitiveness. We then present the hypotheses on the direct effects of the firm's resources and capabilities and the tourism destination on tourism competitiveness, and the moderating effect of location in a tourism destination on the firm effect. The methodology, the database and the measurement of the model variables are then described, and the results reported and analyzed. The paper ends with the main conclusions and limitations of the study.

\section{THEORY}

\section{The firm effect}

The Resource-Based View (Barney, Wright, \& Ketchen, 2001; Amit \& Schoemaker, 1993) is the most widespread theory applied to uncover the mechanisms underlying the 'firm effect'. This view recognizes the importance of each firm's resources and capabilities in obtaining and sustaining competitive advantage. As a complement to the RBV, the Dynamic Capabilities-Based View (DCBV) emphasizes the strategic value of assets known as dynamic capabilities, which act as catalysts for innovation and for the processes that generate and renew the firm's resources and capabilities (Eisenhardt \& Martin, 2000; Teece, Pisano, \& Shuen, 1997; Nelson \& Winter, 1982).

Resources are the assets that the firm possesses or controls, whereas capabilities refer to the firm's skill in exploiting and combining these resources through organizational routines in order to achieve objectives (Amit \& Schoemaker, 1993). The literature has classified resources and capabilities according to two criteria: (i) distinguishing between tangible and intangible assets (Barney, 1994; Teece, Rumelt, Dosi, \& Winter, 1994; Grant, 1991a; Collis, 1991); and (ii) based on the idea that these capabilities are organized according to a certain hierarchical structure, at the bottom of which are the functional capabilities, on the second level are the coordination capabilities or capabilities for integrating the functional capabilities and, finally, the higher level or dynamic capabilities at the top (Lawson \& Samson, 2001). Combining these two criteria is interesting both because the distinction between tangible and intangible assets is a critical point since their potential to create value is very different and because adopting a hierarchical typology of capabilities opens the door to study the interactions among capabilities of different levels. By combining these two approaches, a firm's assets can be classified in the following groups:

- Tangible assets:

- Physical resources: these include all tangible resources with a material or physical component.

- Financial resources: these resources are found in the firm's financing structure and enable it to make investments in other areas. This structure is limited to the firm's liquid assets, its financial investments, its debt capability and its own financing capability.

- Intangible assets:

- Dynamic or higher-order capabilities: these cover all the firm's unique competencies for creating, capturing and transferring knowledge in the organization and its application in innovation. They therefore include R\&D capabilities (Zhara \& George, 2002; Cohen \& Levinthal, 1990).

- Coordination or integration capabilities: these capabilities are related to the firm's human capital (managerial or otherwise) and to the development and dissemination of an organizational culture. They concern the coordination of functional capabilities (in this paper we divide them into production and marketing capabilities) and the cohesion of all members of the organization.

- Production capabilities: these include all the skills in managing operations that derive in differentials in cost competences, technological differentiation of the product, quality, time and flexibility.

- Marketing capabilities: these capabilities refer to the assets deriving from the firm's external relationships, knowledge about the market and customers, marketing management capabilities and reputation. 


\section{The destination effect}

The strategic importance of the tourism destination to which the firm belongs lies in its nature as a space that bounds its activity and as a potential source of advantages that strengthen all the firms located within it (Camisón \& Forés, 2011). The tourism destination offer is determined by a mix of products that influences the tourism experience and acts within a determined geographical parameter and generates a differentiated image (Lim \& Weaver, 2014). Although the integrated tourism product and the tourism destination are separate entities, there is an intrinsic relationship between the territorial quality of the destination and the tourism commercialization function. Hence, image, organization, quality and sustainability are key factors for the competitiveness of tourism products (Pardellas, 2006). Indeed, every tourist product that is situated in a region and an environment with unique attractions can become commercially exploitable tourism resources with value to attract demand from tourism consumers. While some factors can be imitated or improved, the specific characteristics deriving from the location of the tourism destination, such as beaches, natural environments, history, culture, location, etc., are differentiating attributes that are unique to each destination (Rodríguez-Díaz \& Espino-Rodríguez, 2008).

The influence of the destination is not limited to a simple reductionist spatial perspective as the geographic area in which an integrated tourism product is developed. The tourism destination is also the confluence of agents who over time forge a network of firms specialized in differentiated areas of leisure satisfaction. This vision is linked to the interpretation of the tourism destination as a district in the Marshallian sense of the term (Aurioles, Fernández, \& Manzanera, 2008; Fernández, Manzanera, \& Aurioles, 2008), thus giving rise to the concept of the tourism district (Molteni \& Sainaghi, 1997). The study of destinations from this viewpoint has been relatively neglected (Morrison, Lynch, \& Johns, 2004), as the services observed have been defined as auxiliary activities (Hjalager, 2002). However, a research stream that has been attracting growing interest since the 1990s analyzes the implications of the formation of networks and clusters in the tourism and hospitality sector (Erkuş-Öztürk, 2009; Canina, Enz, \& Harrison, 2005; Saxena, 2005; Hall, 2005; Michael, 2003; Nordin, 2003; Tinsley \& Lynch, 2001).

Sainaghi (2006:1054) states that in the concept of the tourism district it is possible to identify constituent elements of a district according to the canonical or Marshallian approach that have been considered as an advantage for the firms located within it. These elements are: a well-defined geographical area with a high density of small and medium-sized enterprises specializing in some activities in the value chain; access to qualified labor, knowledge and new ideas (Belussi \& Pilotti, 2002); and a shared culture.

The updating of the original Marshallian concept by Becattini (1990) defines the industrial district as a socioterritorial entity which frequently includes interfirm networks and a community of people with both a strong sense of belonging and common cultural values. In this vein, the competitiveness of this organizational model depends on the density of the cooperation networks among intra-district firms, which determine the volume of economies of agglomeration that cooperating firms can obtain. Network economies can be found in the flows of experience, information and knowledge circulating with few restrictions in the district; the rapid dissemination and absorption of innovations and new skills; the existence of technological spillovers and an infrastructure of regionally or locally based institutional strength (Camisón, 2004). Trust through mutual knowledge and sustained reproduction of cooperative relationships between the agents within the district reduces opportunism (Foss \& Koch, 1996), which generates low transaction costs and supports individual and collective learning processes. Therefore, the tourism destination as a district comprises different types of organizations that at the same time compete and complement each other, multiple subsectors, infrastructures and a large number of public and private connections (Pavlovich, 2003).

\section{HYPOTHESES}

\section{The importance of the firm effect to tourism firm competitiveness}

As service companies, tourism firms tend to be less intensive in physical resources (Orfila-Sintes, Crespí-Cladera, \& Martínez-Ros, 2005) than other industrial firms. However, they are at the same time obliged to make capital investments in the premises and physical infrastructure necessary to provide the service and to organize their set of resources. Nonetheless, as tangible assets that can be easily observed and acquired in markets organized by their competitors, the tourism firm will not easily be able to build lasting competitive advantages by exploiting its physical resources.

Even in the unusual case that the consumer's choice and perceived value were closely linked to the firm's fixed assets, it would not be too difficult for a competing firm to replicate its competitors' facilities. The value of the physical assets might lie in their combination with other types of resources to develop capabilities that are more resistant to imitation (Camisón, 2004; Teece et al., 1997; Amit \& Schoemaker, 1993). Thus, investment in tangible resources is a necessary condition, but it is not sufficient for the tourism firm to be able to differentiate its competitive position, since the strategic value of these physical resources is lower on an individual level, which leads to our first hypothesis:

Hypothesis 1: Physical resources do not influence the tourism firm's competitiveness.

In contrast, financial resources are particularly relevant as part of an organizational configuration that can favor and safeguard the accumulation of strategic assets. Cost efficiency helps to construct a competitive position differentiated in prices (Grant, 1991b). A secure financing capability allows the firm to guarantee the flow of funds used to accumulate tangible assets and develop functional and innovative capabilities (Amit \& Schoemaker, 1993). Although there is an organized financial market that firms can turn to, stable access to financing at a competitive price is not easy to come by in today's climate of credit scarcity. Only firms that can provide financial intermediaries with significant guarantees of profitability and security are able to obtain financial 
resources in the conditions of cost, time and volume that they need for their operations and to improve their processes, products and personnel. Therefore, financial strength is a capability that is difficult to replicate, valuable and scarce. The above argument leads to our second hypothesis:

Hypothesis 2: Financial resources positively influence the tourism firm's competitiveness.

The firm can be conceptualized as an entity that is capable of acquiring, developing and accumulating knowledge (Carbonara, 2004); this knowledge is absorbed by the firm (Cohen \& Levinthal, 1990) and embedded in technologies, individual capabilities and organizational routines (Nelson \& Winter, 1982). Innovation capability is essential in providing innovative goods and services that help to obtain a competitive advantage (Gursoy \& Swanger, 2007; Conner, 1991). Specifically, tourism firms operate in a highly competitive sector that is continually transforming and, therefore, where innovation is imperative for survival (Sundbo, Orfila-Sintes, \& Sørensen, 2007). Innovations allow the tourism firm to offer valuable, rare, inimitable and differentiated products and services (Gursoy \& Swanger, 2007). Hence, the following hypothesis suggests that the development of dynamic capabilities will have a positive effect on the competitive position of tourism sector firms.

Hypothesis 3: The development of dynamic capabilities positively influences the tourism firm's competitiveness.

The RBV highlights the importance of human resources and organizational culture as crucial factors in developing sustainable competitive advantages, as they are difficult to imitate or replicate (Barney \& Wright, 1998; Lado \& Wilson, 1994). Given the intense and direct nature of the contact between the tourism firm personnel and the end consumer, people-related capabilities are if anything even more important. However, even when it has excellent qualities, human capital might not lead to competitive advantages if it is not managed correctly and guided toward certain targets. Managerial capabilities are therefore crucial in understanding and managing the potential for generating value from the rest of the firm's resources (Castanias \& Helfat, 2001; Mahoney, 1995) and acting as a catalyst of other capabilities (Martínez, Charterina, \& Araujo, 2010). Managerial capabilities enable the coordination of functional and dynamic capabilities, creating a mission that guides the formulation and implantation of the strategy that forms the basis on which to develop the rest of the firm's competencies (Lado \& Wilson, 1994). Because managers' tacit knowledge assets are capabilities that are very heterogeneous and difficult to imitate (Hambrick, Cho, \& Chen, 1996), the following relationship is proposed:

Hypothesis 4: The development of coordination capabilities positively influences the tourism firm's competitiveness.

Quality has been extensively used as a reliable measure of production capabilities. The RBV considers quality to be a strategic asset due to its potential to create long-term sustainable competitive advantages (Eldridge, Balubaif, \& Barber, 2006; Reed, Lemak, \& Montgomery, 1996). Although quality is considered to be a key factor for firms, total quality management has not been widely applied in the hotel industry as managers do not consider it to be necessary in their firms (Lazari \& Kanellopoulos, 2007). However, empirical studies show that hotels with a commitment to total quality are more profitable and that total quality management improves customer satisfaction and, in the final instance, performance (Wang, Chen, \& Chen, 2012; Agus, Krishnan, Latifah, \& Kadir, 2000). In turn, service quality in tourism is seen as a necessary and important strategy for competitiveness (Augustyn \& Ho, 1998). Reputation is another valuable capability, particularly in services like tourism where product quality is not easily perceived by the customer, or where it is critical for technological or security reasons (Aaker, 1989). The above arguments lead us to propose that:

Hypothesis 5: The development of production and quality capabilities positively influences the tourism firm's competitiveness.

Marketing capabilities are of great importance to organizations (Hunt \& Morgan, 1995; Hooley, Greenley, Cadogan, $\&$ Fahy, 2005). Aspects such as customer relations or market orientation are key to creating and sustaining competitive advantage (Wang et al., 2012; Srivastava, Fahey, \& Christensen, 2001). As well as adding value for the customer (Gursoy \& Swanger, 2007), marketing capabilities give firms a better understanding of consumers' present and future needs and preferences, and enable them to anticipate actions their competitors might undertake (Hamel \& Heene, 1994). Marketing capabilities allow firms to gather external information (customers, markets, etc.) and disseminate it through the firm, helping managers take decisions and providing other areas with knowledge about consumers' changing needs and the strategies of their competitors (Gursoy \& Swanger, 2007). These arguments lead us to propose the following hypothesis:

Hypothesis 6: The development of marketing capabilities positively influences the tourism firm's competitiveness.

\section{Importance of the 'destination effect' in tourism firm competitiveness}

Clusters, or districts, offer the firms located within them a series of benefits. The purpose of districts is to draw attention to the availability of certain activities in a territory and to enable SMEs that normally work in isolation to cooperate and build an integrated, successful tourism product (Novelli, Schmitz, \& Spencer, 2006; Pavlovich, 2003; Tinsley \& Lynch, 2001). Combining the offers of the firms in a tourism destination in a coordinated way to create an integrated tourism product will create externalities and attract customers more effectively than if each firm operates individually (Kalnins \& Chung, 2004). Location in a destination also brings other advantages such as access to skilled labor, lower transaction costs, shared costs for specialized infrastructures, availability of external knowledge from the district's global information sources (Bathelt, Malmberg, \& Maskell, 2004) and exchange of information, technology and learning processes (Morrison et al., 2004). Our next hypothesis is therefore: 
Hypothesis 7: Integration in a tourism district positively influences the tourism firm's competitiveness.

\section{Importance of interaction between firm effects and desti- nation effects to tourism firm competitiveness}

The most striking improvement in competitive position will be seen in the destination firms that are best able to take advantage of the opportunities the destination offers to develop and acquire their own resources and capabilities (Camisón \& Monfort, 2012; Camisón \& Forés, 2011; Orfila-Sintes et al., 2005; Hjalager, 2002). We therefore propose that the tourism destination effect on tourism firm competitiveness can act as a moderator of the strength of each organization's own resources and capabilities.

We argued above that it would be difficult for firms to build sustainable competitive advantages based on their physical resources due to the ease with which they can be observed and imitated (Camisón, 2004). However, when the tourism firm is located in a district, location can become more valuable because of the limited space available in the heart of the destination, and firms situated in the best locations will be more attractive to tourists (Erkuş-Öztürk, 2009; Smith, 1994). The growth of tourism destinations has traditionally been based on location advantages, which derive from privileged tangible assets. This is the case, for example, of resorts like Benidorm, whose expansion has benefited from a special micro-climate and high quality beaches, or cultural destinations that have become successful by exploiting their historical assets. Moreover, by attracting higher demand flows, intra-destination firms will be able to maximize their fixed asset investments and thus gain cost efficiencies. Therefore, firms located in the district augment the potential of their physical resources through their interaction and combination with other tangible (natural, scenic or historical) and intangible (brand image, reputation and value system) resources located in the district.

In light of the above we propose the following hypothesis:

Hypothesis 8a: The positive effect of possessing physical assets on the tourism firm's competitiveness will be greater when the firm is located in a tourism district.

The financial strength of a tourism firm can also be enhanced if it is located in a destination (Orfila-Sintes et al., 2005; Camisón, 2004). In this case, investor and lender confidence can be strengthened by the halo effect the destination provides. Furthermore, association among intra-district firms gives them more weight in negotiations with financial entities, which can bring advantages in accessing capital (Camisón, 2004). The stock of financial resources in the heart of the district can also be advantageous in terms of grants that public bodies frequently make available to stimulate and revitalize destinations. The following relationship is therefore proposed:

Hypothesis 8b: The positive effect of possessing financial resources on the tourism firm's competitiveness will be greater when the firm is located in a tourism district.

In general the industrial districts literature claims that location in a district encourages innovation in the firms within it (Bell, 2005; Porter, 1990) because, among other reasons, they can benefit from advantages such as exploiting collective knowledge (Dosi, 1988) or knowledge gained from social interaction (Harrison, 1992). The ability to create joint knowledge and absorptive capability are key factors in coordinating cooperation effectively and efficiently. However, location in a district can also reduce the investment in innovation that the firms in the district make (Maskell \& Malmberg, 2007; Henderson \& Cockburn, 1996; Bernstein \& Nadiri, 1989) due to the risk that internal generation of knowledge may be exploited by neighboring competitors. This risk is particularly high in tourism districts (Hjalager, 2002). Innovations in services tend to be easy to imitate because, as they do not involve advanced technology, they are simple and therefore more easily observed and imitated. In addition, tourism firms obtain fewer innovation benefits from being embedded in a tourism district because their relationships with research institutions are limited, and as a result, they do not enjoy the advantages of such institutional support (Howells, 2004).

Moreover, knowledge transfer in the tourism sector is hampered by a value chain with a low level of innovation accumulation (Weiermair \& Peters, 2002) and where opportunities for the dissemination of knowledge and technology are frustrated by weak relationships with customers and other suppliers. Indeed, this argument might explain why service firms (such as tourism firms) are less inclined to participate in networks (Sundbo et al., 2007). In this vein, empirical evidence shows that a low proportion of tourism firms cooperate in innovation with all types of organizations (Camisón \& Monfort, 2012; Novelli et al., 2006). Long-term trust building is hindered by high staff turnover. Likewise, because firms are very heterogeneous in terms of size, type and affiliation, sharing common objectives in tourism destinations is complicated or impossible (Hjalager, 2002). Many tourism destinations lack a sense of corporate identity, which makes it difficult to establish and work toward a global vision or goal (Schianetz, Kavanagh, \& Lockington, 2007). Collaboration tends to occur through intermediary institutions that manage the destination and that play a key role in the knowledge transfer process (Camisón \& Monfort, 2012); as a result, some of the effects of cooperation can be lost (Hjalager, 2002). Therefore, tourism firms located in the same destination do not necessarily take advantage of the innovative synergies that arise from the opportunity to cooperate with other firms in the district. In addition, innovation in tourism is an intrinsically territorial phenomenon that depends on the resources bound to specific locations and that are therefore impossible to reproduce in other places (Longhi \& Keeble, 2000).

In light of the above, we propose the following hypothesis:

Hypothesis 8c: The positive effect of possessing dynamic capabilities on the tourism firm's competitiveness will be weaker when the firm is located within a tourism district.

The key capabilities needed to manage and capitalize on tourism networks lie in the skill to orchestrate and view the network as a way of strengthening the commitment of the actors to the ideology of the common brand (Lemmetyinen \& 
Go, 2009). This commitment can be considered as a coordination skill. To ensure continuity of the value creation process, a strong capability for union and partnering is needed. Location in a tourism district with a dense network of cooperation agreements could therefore be an incentive to develop this capability. Likewise, the availability of specialized qualified personnel and a strong feeling of embeddedness in the destination's social community can help managers secure more productive human capital and align it with a view of the business that follows the commonly accepted tradition and image of the territory (Novelli et al., 2006; Camisón, 2004). The following hypothesis reflects the above arguments:

Hypothesis 8d: The positive effect of possessing coordination capabilities on the tourism firm's competitiveness will be greater when the firm is located within a tourism district.

A tourism destination's offer is determined by the product mix within a specific geographical perimeter where the particular way factors are used generates a differentiated, specific image of the whole tourism product. (Lim \& Weaver, 2014) Thus, the management of the destination will focus on the activities that make it more attractive to customers, for which a joint effort will be needed to enhance the quality and improve the services offered by the destination firms (Molina-Azorín et al., 2010; Saxena, 2005). In other words, the benefits of developing a joint marketing strategy for the destination will multiply when the firms located in it align their promotion campaigns, price policies and selection of target markets with the destination's image. Therefore, the development of marketing capabilities will be strengthened when the firm's marketing strategy is planned to be coherent with the destination (Erkuş-Öztürk, 2009; Saxena, 2005). Location in the destination should result in greater marketing capabilities such as brand and reputation, which now combine the individual strength of each firm and the image of the destination, thereby increasing competitiveness at both levels. The firm's production capabilities can therefore be strengthened when its quality policy is aligned with and takes advantage of the synergies characteristic of the destination. The availability of nearby firms in the entire value system, together with the opportunities afforded by the resources specific to the destination, favors productive capabilities such as quality and efficiency in service provision (Novelli et al., 2006; Camisón, 2004; Belussi \& Pilotti, 2002). We therefore propose the following two hypotheses:

Hypothesis 8e: The positive effect of possessing production and quality capabilities on the tourism firm's competitiveness will be greater when the firm is located within a tourism district.

Hypothesis 8f: The positive effect of possessing marketing capabilities on the tourism firm's competitiveness will be greater when the firm is located within a tourism district.

\section{Control variables}

We introduce the variable general environment effect to capture the influence of differences among geographical areas in aspects such as hostility toward industry, uncertainty and turbulence. It is clear that the higher the levels of hostility, uncertainty and turbulence in the general environment, the more difficult it will be for the firms located in it to achieve competitive advantages.

In addition, Spain's economic, political and social system is a markedly heterogeneous, where fierce competition can arise among regional institutions to create a more attractive structure to develop business activity. We therefore include the variable regional effect in our theoretical model, which captures the regional differences in the stock of resources and public policies.

Finally, we introduce the variable industry effect to capture the influence on the firm's competitive position of the attractiveness of the sector's structure in terms of threats from substitute products and new competitors, customer and supplier negotiating power and the level of competition among already established rivals. Two further control variables are included in the model to reflect aspects of the firm's composition: organizational size, measured by the total number of employees, and the age of the firm, considered as the number of years in operation.

\section{MATERIALS AND METHODS}

\section{Database}

The empirical study was carried out using a database of Spanish tourism firms created from an initial study. The research plan involved requesting an ad hoc process from the National Statistics Institute's Central Directory of Spanish Companies (DIRCE) in order to determine the reference universe and its geographical distribution by activity, size, autonomous community and province. On the basis of these data the sample distribution was designed for a target size of 1000 firms, which assumed a 95\% confidence level and an error interval of $\pm 3.1 \%$. The resulting sample was selected from the information provided by the DIRCE using a stratified random procedure set in proportion to the representativeness of the universe by activity (considering the five groups mentioned) and size (measured in terms of number of employees in the firm).

The final sample contained 1019 firms distributed as follows: $62.71 \%$ were microfirms; $25.22 \%$, small firms; $9.62 \%$, medium-sized firms and $2.45 \%$, large firms. By tourism activity, $30.03 \%$ of the firms provided accommodation, $37.88 \%$ were restaurants and catering firms, almost $11 \%$ were intermediaries (travel agencies, tour operators, etc.), $3.93 \%$ were transport organizations and $17.17 \%$ fell into the complementary offer category.

The fieldwork consisted of personal interviews previously arranged by telephone and using questionnaires. The telephone conversation was also used to confirm data about the firm, in order to verify the reliability of the information gathered from external sources that had led to the firm's random inclusion in the sample (activity, size and location), and to ensure that the person matched the desired respondent profile. We considered that the firm's owner, the senior/general manager or CEO of the company was the most appropriate 
person to respond to the questionnaire. We used a set of procedures recommended for survey research and involving a modified version of Dillman's (1978) total design method. Specifically, the questionnaire design took into account a large number of instruments used for similar purposes in research on competitiveness and dissemination of organizational innovations and practices.

The final questionnaire was refined in various stages to ensure it was fully comprehensible and efficient in gathering the desired information, and to reduce its length and consequent administration time. The refining process took place in meetings between the head of the research team and professionals from the company contracted to carry out the fieldwork. Before applying the final questionnaire to collect the data it was pretested on a group of five academics specializing in the fields of tourism and strategy. This pretest was held in the first two weeks of November 2009. The resulting questionnaire was then also administered to eight managers from firms of different sizes and activities in the tourism sector. The managers' comments and suggestions for improvement were taken into account in the final questionnaire design. To avoid the risk of automatic unconsidered responses, the order of the responses was altered so that in some cases the order of desirability was ascending and in others, descending. Control items were also included in which the meaning of the statement was reversed compared to the other scale items. A third mechanism used was the inclusion of questions on the same topic in different formats and sections of the questionnaire to control for response reliability. The fieldwork took place between December 2009 and March 2010.

We also performed a number of statistical analyses to assess the severity of common method bias. First, a Harman's one factor test on the items indicated (see Table 1) that this bias was not an issue. That is, multiple factors were detected, and the variance did not merely stem from the first factors (Podsakoff, MacKenzie, Lee, \& Podsakoff, 2003; Podsakoff \& Organ, 1986). In fact, the independent variables included in the model form several factors with eigenvalues higher than 1 and the first two factors capture only 26 and $11 \%$ of the total variance, respectively. We also included control variables that have a bivariate correlation below 0.3 (Siemsen, Roth, \& Oliveira, 2010) between each other and the other variables in the model.

The statistical tests do not eliminate the threat; however, they suggest that our results are not driven predominantly by common method variance. Moreover, our results are based on complex estimations that involve multiple independent variables and interactions terms. It has been argued that it is highly unlikely that the results of such models emerge solely as a result of common methods bias (Siemsen et al., 2010). To assess the severity of multicollinearity, we computed variance inflation factors (VIFs) with an average VIF value of $y$ and the maximum VIF value of 2.683, which are well below the cut-off point of 10 (Cohen, Cohen, West, \& Aiken, 2003), implying that multicollinearity does not pose a problem to our estimation models.

\section{Measurement of variables}

Most of the variables were measured on multi-item sevenpoint Likert-type scales. In the cases of competitive position, capabilities and stock of financial resources, the measures reflect the strength of the firm as compared to its industry competitors ( $1=$ 'much worse', $2=$ 'worse', 3 = 'slightly worse', $4=$ 'on a par', $5=$ 'slightly better', $6=$ 'better' and $7=$ 'much better'). The firm's physical resource stock was measured by the number of years since the last major renovation of its tangible assets. The age of a tourism firm's premises can be considered as an acceptable proxy of its tangible asset stock.

Production capabilities are quite difficult to measure on a single scale when firms that provide very differentiated services are being analyzed, our sample includes firms with a range of different activities such as accommodation, catering, travel agencies and tour operators, transport and complementary offer. In light of this difficulty, we adopted quality capabilities as an acceptable proxy for production capabilities (Camisón and Monfort, dirs. 2012), considering the high positive association shown in the literature among product and process operations and quality (e.g. Koufteros, Vonderembse, \& Doll, 2002; Tatikonda \& Montoya-Weiss, 2001). This association between quality and production capabilities lies in the fact that firms which are granted a quality certificate demonstrate an excellent process organizational capability measured against the average level of their competitors. Hence, the higher the firm's quality capability, the greater its capability to provide services in line with certain standards and to manage processes efficiently.

To classify the sample firms within Spanish tourist districts, we used the list of Spanish tourism districts proposed by Fernández et al. (2008) and Aurioles et al. (2008). Location in a district or not was considered as a dichotomous variable where 1 represented location in a tourism district and 0 otherwise.

The control variables were measured as follows. The frame of analysis for the 'regional effect' was the region in which the firm is based, and its attractiveness was measured using data from the EU Regional Competitiveness Index, which measures the competitiveness of European regions. The general environment effect and the industry effect were measured with multi-item seven-point Likert-type scales reflecting managers' perceptions of the presence of certain variables related to the environment $(1=$ 'very low', $2=$ 'low', 3= 'quite low', 4= 'average', 5= 'quite high', $6=$ 'high' and $7=$ 'very high'). Objective measures were used to quantify firm size and age, namely, the number of employees and the number of years the firm had been operating, respectively.

Table 1 presents the main characteristics of the variables included in the model. Although most of the scales used have been validated in previous research, in this study it was deemed appropriate to refine them by means of a reliability analysis to ensure their internal consistency. The generally accepted minimum of 0.7 for Cronbach's alpha reliability coefficient was exceeded for all the scales with the exceptions of the general environment and industry structure scales; because of their exploratory nature, a minimum value of 0.5 was considered to be acceptable (Hair, Anderson, Tatham, \& Black, 1998). The convergent validity of the dependent variable was also verified with objective internal (concurrent 





validity) and external (predictive validity) measures of the firm. Specifically, concurrent validity was tested by verifying whether the measure of the firm's competitive position based on the manager's perceptions was convergent with the objective measure of the degree of average annual occupancy of installed capability(\%).The Pearson correlation coefficient between the two variables was positive $(r=0.207)$ and statistically significant $(\mathrm{p}<0.001)$. Predictive validity was verified by means of the correlation between the measure of competitive position and organizational performance. Performance was operationalized with the economic performance indicator from the annual accounts for 2008 compiled in the SABI (Sistema de Análisis de Balances Ibéricos) database. The results revealed positive correlations $(\mathrm{p}<0.05)$ between competitive position and economic performance $(\mathrm{r}=0.106)$. Table 2 presents the descriptive statistics and the correlations of the study variables.

\section{Methodology}

The study applied multiple linear regression analysis using the SPSS 21.0 program for Windows. The results are statistically robust, as compliance with the basic assumptions for regression analysis was verified by an analysis of the residuals and of other graphs and statistics provided by the program (see Annex). Furthermore, we centered the independent variables before creating their cross products (Cohen et al., 2003). The estimated coefficients demonstrate a similar pattern to our main results in Table 3.

\section{RESULTS AND DISCUSSION}

\section{Results}

Two types of relationships can be differentiated in the proposed hypotheses: direct effects ( $\mathrm{H} 1$ to $\mathrm{H} 7)$, and the moderating effect of location in a destination (H8a to H8f). We developed three different models to test the hypotheses. The first model included the control variables only; the second model included the control variables and the explanatory variables and the third model comprised all the relationships, showing the effects of the control and explanatory variables and the moderating effects.

Table 3 displays the results of testing the model with all the proposed relationships. The significance of the F statistic is acceptable for all the estimated models. An increase in the explanatory capability of the models can be seen when first the explanatory variables and then the moderating effects are introduced. In the case of the complete model with the direct and moderating effects, the adjusted $\mathrm{R}^{2}$ shows a capability to explain the competitive position of $39.8 \%$.

An initial analysis confirms that a large number of aspects, both internal and external to the firm, influence its competitiveness. However, the comparison of models II and III reveals differences in the extent of the significance of the effect. This indicates that the moderating variable has a strong influence on the results, and brings to light relationships that remain hidden when the model is limited to direct effects. Likewise, an overall analysis shows that location in a tourism district significantly, although heterogeneously,




Table 3. Results of the regression of the determining factors of a tourism firm's competitiveness

\begin{tabular}{|c|c|c|c|c|c|c|c|}
\hline & & \multicolumn{2}{|c|}{ Model I } & \multicolumn{2}{|c|}{ Model II } & \multicolumn{2}{|c|}{ Model III } \\
\hline & & (1) & (2) & (1) & (2) & (1) & (2) \\
\hline \multicolumn{2}{|c|}{ Constant } & $3.814(3)$ & & $-0.425(3)$ & & $0.467(3)$ & \\
\hline \multicolumn{8}{|c|}{ Control variables } \\
\hline 1 & General environment & 0.018 & 0.419 & -0.061 & -1.518 & $-0.068 *$ & -1.673 \\
\hline 2 & General regional environment & $0.185 * * * *$ & 4.517 & $0.102 * *$ & 2.474 & $0.099 * *$ & 2.406 \\
\hline 3 & Industry effect & $0.084 * *$ & 1.971 & $0.073 *$ & 1.825 & $0.080 * *$ & 1.979 \\
\hline 4 & Size & $0.082 * *$ & 2.015 & -0.006 & -0.161 & -0.015 & -0.386 \\
\hline 5 & Age & 0.043 & 1.043 & $0.091 * *$ & 2.302 & $0.078 *$ & 1.952 \\
\hline \multicolumn{8}{|c|}{ Explanatory variables } \\
\hline 6 & Physical resources & & & -0.020 & -0.499 & -0.078 & -1.087 \\
\hline 7 & Financial resources & & & $0.169 * * * *$ & 4.051 & $0.336 * * *$ & 3.168 \\
\hline 8 & Dynamic capabilities & & & 0.054 & 1.107 & $0.406 * * *$ & 2.799 \\
\hline 9 & Coordination capabilities & & & $0.183 * * * *$ & 3.639 & -0.248 & -1.491 \\
\hline 10 & Production and quality capabilities & & & $0.243 * * * *$ & 4.466 & $0.397 * *$ & 2.147 \\
\hline 11 & Marketing capabilities & & & $0.144 * * *$ & 2.810 & -0.067 & -0.505 \\
\hline 12 & District & & & 0.035 & 0.873 & -0.292 & -1.067 \\
\hline \multicolumn{8}{|c|}{ Interaction between variables } \\
\hline 13 & Physical resources $\times$ district & & & & & 0.071 & 0.964 \\
\hline 14 & Financial resources $\times$ district & & & & & -0.391 & -1.644 \\
\hline 15 & Dynamic capabilities $\times$ district & & & & & $-0.543 * *$ & -2.507 \\
\hline 16 & Coordination capabilities $\times$ district & & & & & $1.066 * * *$ & 2.709 \\
\hline 17 & Production capabilities $\times$ district & & & & & -0.339 & -0.840 \\
\hline \multirow[t]{5}{*}{18} & Marketing capabilities $\times$ district & & & & & $0.490 *$ & 1.683 \\
\hline & $\mathrm{F}$ & $6.736 * * * *$ & & $24.114 * * * *$ & & $17.080 * * * *$ & \\
\hline & $\mathrm{R}^{2}$ & 0.054 & & 0.404 & & 0.423 & \\
\hline & Adjusted $\mathrm{R}^{2}$ & 0.046 & & 0.388 & & 0.398 & \\
\hline & Adjusted $\Delta \mathrm{R}^{2}$ & - & & 0.350 & & 0.019 & \\
\hline
\end{tabular}

(1) Standardized regression coefficients.

(2) $t$-values.

(3) Non-standardized beta.

$* \mathrm{p}<0.1$.

$* * \mathrm{p}<0.05$

$* * * \mathrm{p}<0.01$

$* * * * \mathrm{p}<0.001$

moderates the influence of the firm's capabilities and resources on its competitiveness.

Financial resources have a direct and significant relationship with competitive position that increases in model III $(0.336, \mathrm{p}<0.01)$. In contrast, physical assets do not seem to have an impact on competitive position in any of the models. Both $\mathrm{H} 1$ and $\mathrm{H} 2$ are therefore empirically supported.

Dynamic capabilities are empirically confirmed as the most important factor for competitiveness with the highest standardized coefficient $(0.406, \mathrm{p}<0.01)$ of all the explanatory variables. $\mathrm{H} 3$ is therefore statistically supported. It is noteworthy that this variable is not significant in model II, but becomes significant in model III when the moderating variable is introduced both on its own and together with the variable location in a tourism destination.

Production and quality capabilities are also confirmed as important to tourism competitiveness in both models, and their weight increases in model III $(0.397, \mathrm{p}<0.05)$. H5 can therefore be accepted.

It is surprising, however, that the coordination and marketing capabilities, whose relationship with competitive position was positive and significant in model II, are no longer significant when the moderating effects are introduced. Hence, hypotheses $\mathrm{H} 4$ and $\mathrm{H} 6$ are confirmed in model II but rejected in model III.
Furthermore, H7 is not confirmed, which suggests that the simple fact of location in a tourism district does not directly affect the firm's competitive position.

Turning to the moderating variables for the destination effect, only coordination capabilities $(1.066, \mathrm{p}<0.01)$ and marketing capabilities $(0.490, \mathrm{p}<0.1)$ are significantly and positively influenced, whereas dynamic capabilities are negatively affected $(-0.543, \mathrm{p}<0.05)$. Therefore hypotheses $\mathrm{H} 8 \mathrm{~d}, \mathrm{H} 8 \mathrm{f}$ and $\mathrm{H} 8 \mathrm{c}$ are accepted, respectively, and $\mathrm{H} 8 \mathrm{a}$, $\mathrm{H} 8 \mathrm{~b}$ and $\mathrm{H} 8 \mathrm{e}$ are rejected.

Finally, to reinforce the results of the regression analysis and in order to compare the moderating effects of location in a tourism district on the relationship between these three capabilities and competitiveness, we include a graphic representation of each relationship. Figure 1 shows that integration in a district is associated with greater competitiveness at a higher level of a firm's coordination capabilities. Firms that demonstrate a high level of internal coordination capabilities can take part in and benefit from a district strategic plan and a collective pattern of relationships of suppliers and subcontractors. That is, only those firms with a welldeveloped strategic and organizational design can benefit from exposure to a shared vision and strategy.

As shown in Figure 2 integration in a district is associated with greater competitiveness at a higher level of a 




Figure 1. The moderating effect of district on the relationship between coordination capabilities and competitiveness.



Figure 2. The moderating effect of district on the relationship between marketing capabilities and competitiveness.

firm's marketing capabilities. Only those firms with a robust communication policy and image and with considerable control over their marketing channels can benefit from being located in a tourism district. Firms that aim to exploit the district agents' efforts to promote a common image, reputation and brand of the district product should therefore be at the 'expected' level in their marketing development capabilities.

As shown in Figure 3, integration in a district is associated with greater competitiveness at a lower level of a firm's dynamic capabilities. This suggests that firms with greater dynamic capabilities require relatively less exposure to district knowledge flows to be competitive. This effect reconfirms that integration in a district may exert isomorphic pressure or have a lock-in effect (e.g. Maskell \& Malmberg, 2007) that can weaken the capacity to explore new combinations of knowledge and, thus, the creativity of those firms with higher levels of dynamic capabilities. Nevertheless, those firms with weaker dynamic and innovation capabilities can obtain greater competitiveness if they are integrated in a tourism district.

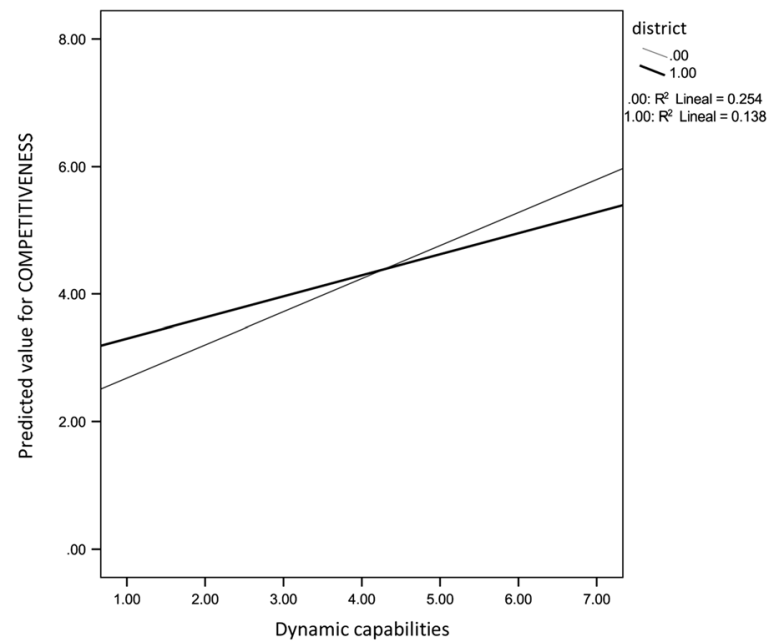

Figure 3. The moderating effect of district on the relationship between dynamic capabilities and competitiveness.

All the control variables except size affect the tourism firm's competitiveness significantly and with the expected sign. Age has a direct and positive effect $(0.078, \mathrm{p}<0.1)$, in line with previous studies concluding that older firms have more experience (Rao \& Drazin, 2002) and reputation (Zaheer \& Bell, 2005), which enhances their routines, systems and structures and, therefore, their competitive potential (Sorensen \& Stuart, 2000). The analysis of the coefficients also reveals that the firm's competitive position is influenced by the attractiveness of the region in which it is located (0.099, $\mathrm{p}<0.05)$ and of the industry $(0.080, \mathrm{p}<0.05)$, whereas the turbulence of the general environment negatively affects the firm's competitiveness $(-0.068, \mathrm{p}<0.05)$.

\section{CONCLUSIONS}

This study examines the effects of the tourism firm's resources and capabilities and location in a tourism district on competitive position, and also analyzes the moderating effects of location within a tourism destination.

The first conclusion we can draw is that the empirical study supports the thesis of the RBV, since resources and capabilities have a much higher ability to explain firm competitiveness than factors related to the environment and other internal organizational characteristics such as size or age. However, when we analyze their effect on the tourism firm's competitiveness some of our results were as expected whereas others were surprising, which suggests asymmetry among the different types of resources and capabilities in their ability to create performance differentials.

Second, it should be noted that simple location in a tourism destination has no significant influence on firm competitiveness. This is an interesting result as it prompts us to reconsider the importance that much of the tourism literature gives to the territory as a material support. This result may indicate that even though intra-district firms can take advantage of the benefits of location in a district (Molina-Azorín et al., 2010), the influence of these external shared resources will depend on how each individual firm makes use of them. 
The simple fact that certain firms are located in the same destination does not imply that these firms cooperate or share the same values, and, in consequence, they will not necessarily comprise a tourism district.

Our third conclusion is that capabilities are better able than resources to create competitive advantages. We found that only financial resources have a significant effect, which is quite lower than the combined effect of capabilities. Given the considerable investment needed to set up a tourism business (Hjalager, 2002), some financial resources will be essential, so advantages in costs and debt capability will be relevant to achieving a sustainable competitive advantage. In contrast, physical resources have no significant influence in any of the cases. Tourism represents a different kind of exchange where no physical resources are sold. This factor reduces the power of the investment in physical capital to create value. The type, quantity and quality of the resources available to the firm have an important bearing on what firms can do because they place restrictions on the activities firms can undertake (Grant, 1991b). But few resources are productive on their own. It is the firms' specific capabilities that hold sway over the transformation of resources into products, creating value added by developing activities and stimulating the other resources. This finding therefore also suggests that location in a destination does not enhance the capability of physical resources to contribute to tourism firm competitiveness. To be competitive factors, attractiveness of the destination's natural resources, together with the tangible assets specific to each firm, needs to be coordinated with other resources to increase their value creation abilities.

It is in this way, by looking beyond locality, that coordination capabilities become a key competitive factor. Nonetheless, it is important to stress that these coordination capabilities act differently depending on whether we consider location in a tourism district or not. When this location factor is not considered (model II), the firm's independent coordination is sufficient to improve the use of resources and to positively contribute to its competitive position. In contrast, when a firm is embedded in a tourism district, the differentiating competitive factor is the overall coordination capabilities of the destination, normally through the regional agencies and associations that showcase the integrated tourism product based on the system's total offer. Therefore, the cooperation with other organizations in the destination will be the key factor for tourism firms located in a specific destination. Authors such as Lemmetyinen and Go (2009) have highlighted the importance of certain coordinationrelated skills as crucial to strengthening links with and commitment to other firms. Fourth, production capabilities are revealed to be key capabilities for tourism firms in general. The capability to offer a consistent quality service is generally considered to be a basic strategy for competitiveness in tourism (Augustyn \& Ho, 1998). However, the lack of significance in the moderating role of the district appears to show that tourism districts do not generate such substantial advantages as in industrial districts in terms of opportunities for subcontracting, production outsourcing and specialization to gain scale and efficiency in costs.
The results on the significance of marketing capabilities are surprising and require further analysis. When they are not included in model II, marketing capabilities have a positive and significant effect. But when the moderating variable is introduced (model III) they become non-significant. Gursoy and Swanger (2007) also found that there is no direct relationship between marketing capabilities and customer service on financial performance, showing that service strategies can easily be replicated and employees move freely among competitors due to employment opportunities. In contrast, in the latter case location in a tourism district positively moderates the effect of marketing capabilities. Joint marketing and integrated marketing initiatives are not as easily replicated by external firms on their own, and they may therefore enhance the competitive position of organizations inside the destination that benefit exclusively from them. The limited and low investment in developing marketing assets in many tourism firms means that reputation building, penetration of new markets, increasing negotiating power with marketing channels and service satisfaction are entrusted to collective interventions. Only firms that are able to take advantage of this district-level investment will therefore obtain competitive advantages from marketing differentiation.

The competitive importance of dynamic capabilities is frequently referred to. However, in our study these capabilities do not have a significant relationship with the firm's competitive position (model II). Some authors argue that this is because tourism firms are conservative and not especially innovative, and as a result, unless they feel challenged or threatened, they tend to remain rooted in traditional procedures; what is more, this sector lacks the preconditions necessary to foster innovation (Hjalager, 2002). Furthermore, labor force skills in the tourism industry tend to be low and turnover high, which implies that the capability to absorb external information is low in the sector, and only large firms have the staff with a large capability to absorb external knowledge; these are therefore the firms that can develop more complex and advanced innovations (Sundbo et al., 2007).

Nonetheless, this general interpretation should perhaps be revised in light of our results. On one hand, when the variable integration in a tourism district is incorporated (model III), dynamic capabilities have a direct and significant relationship with competitive position; moreover, this effect has the strongest impact of all the resources and capabilities. On the other hand, integration in a tourism district has perverse effects on the value of dynamic capabilities, to the point that its positive effect becomes intensely negative. The previous literature has argued that the tourism destination is characterized by intense internal knowledge and technology flows. In consequence, all the firms located in the district take advantage of the other firms' innovation efforts; in other words, a greater development of dynamic capabilities by some intra-district firms can be counterproductive, as these will be the firms that make greater efforts that will then benefit all the other firms. As Hjalager (2002) states, small firms tend to follow an innovative process only when they are sure that their investment in 
innovation or change is feasible; because it is easy to observe what others are doing in the tourism sector, it is simpler to 'copy' innovations than it is in the industrial sector, and even more so if the firm is located in a district. For this reason, the gains from waiting for others to innovate are probably higher than innovating itself. The consequence of this reasoning is that firms located in a district might tend to rest on their laurels and not pay attention to developing their own dynamic capabilities, relying on other firms' innovations and on the overall attractiveness of the district. Furthermore, repeated interactions among the same groups of economic actors lead to a closed, local mentality that can hamper the search for new business activities, hindering adaptation to new requirements or technologies and perpetuating established beliefs, routines and knowledge (Maskell \& Malmberg, 2007; Glasmeier, 1991). This interplay between opposing forces demonstrates that the innovative process is by no means straightforward and a contingent approach should substitute the simple interpretation of their effects.

This study contributes equally interesting ideas for managerial practice in tourism firms. The managers of these organizations should be aware that their main challenge is to develop capabilities, which are the main drivers of competitiveness, and thereby assess the critical role of intangibles in their competitive strategies. Specifically, they should understand the central role of coordination capabilities, either individual or collective depending on whether or not the firm is located in a tourism district. They should also aim to strengthen their capabilities to provide a high quality service; they should be aware of the positive benefits that belonging to a district can have for marketing capabilities, and the risks for innovative differentiation that location in a concentrated district involves. A solid financial base is also an essential competitive requirement, as without the guarantee of sufficient financial flow it is impossible to take on the large investments in these intangibles, the returns on which are only seen in the long term.

These conclusions must, however, be interpreted with caution, since despite every effort to keep them to a minimum, this study does have certain limitations, particularly regarding the cross-sectional database and its restriction to the Spanish tourism sector. The cross-sectional nature of the study precludes confirmation of causal relationships, which would be desirable. Likewise, our conclusions are valuable to the Spanish tourism sector, but should be extrapolated with caution. The measurement of some variables based on managerial self-assessment is also frequently criticized, but we consider that we have minimized its drawbacks with the rigorous approach taken in gathering the opinions of the surveyed managers, as reflected in their reliability and validity. Finally, a useful line of future research could involve a multilevel analysis that would allow an inter-district comparison of the impact of the specific endowment of shared capabilities in the firm's assets. Furthermore, the structure of capabilities adopted also paves the way to incorporate new interactions between the hierarchical structure of capabilities of the firm in future modeling.

\section{ACKNOWLEDGEMENTS}

The authors gratefully acknowledge financial support from the National Plan for R\&D of Spanish Ministry of Economy and Competitiveness (ref. ECO2012-36780) and from Fundació Caixa Castelló-Bancaixa in the context of the Universitat Jaume I Annual Plan of Research (project ref. P1-1A2011-15).

ANNEX

\section{DURBIN-WATSON:}

\begin{tabular}{|c|c|c|c|c|c|}
\hline \multicolumn{6}{|c|}{ Summary of the model ${ }^{b}$} \\
\hline Model & $\mathrm{R}$ & $\begin{array}{c}\mathrm{R} \\
\text { squared }\end{array}$ & $\begin{array}{l}\text { Adjusted R } \\
\text { squared }\end{array}$ & $\begin{array}{l}\text { Standard } \\
\text { estimation } \\
\text { error }\end{array}$ & $\begin{array}{l}\text { Durbin- } \\
\text { Watson }\end{array}$ \\
\hline 1 & $0.650^{\mathrm{a}}$ & 0.423 & 0.398 & 0.88375 & 1.669 \\
\hline
\end{tabular}

\section{Normal P-P graph of standardized residual regression}






\section{HOMOSCEDASTICITY:}

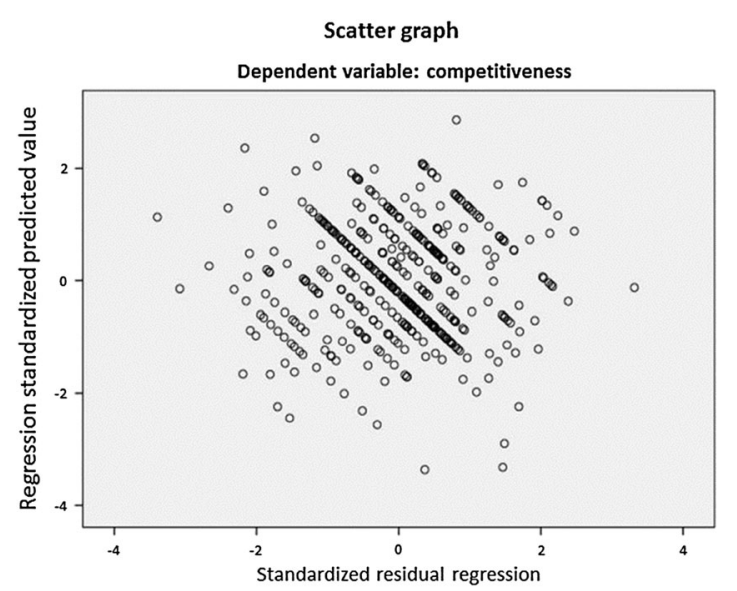

\section{NORMALLY DISTRIBUTED RESIDUAL ERRORS:}

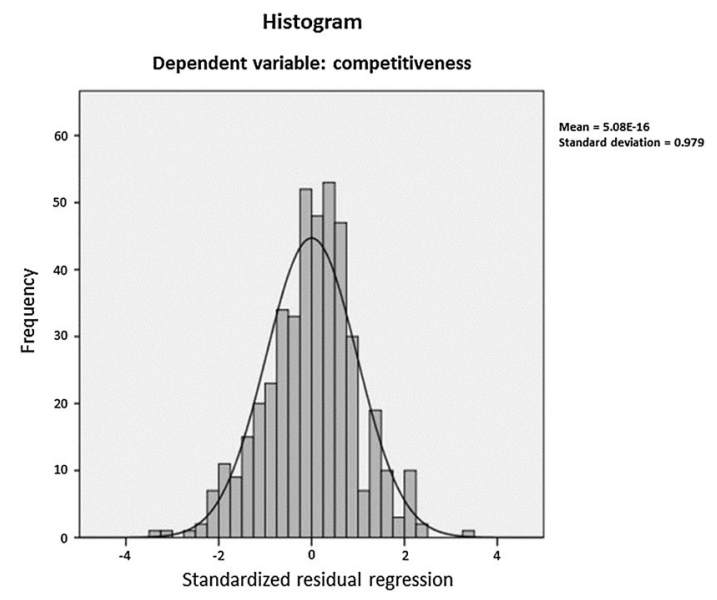

\section{REFERENCES}

Aaker DA. 1989. Managing Assets and Skills: The Key to Sustainable Competitive Advantage. California Management Review 31(2): 91-106.

Agus A, Krishnan SK, Latifah S, Kadir SA. 2000. The Structural Impact of Total Quality Management on Financial Performance Relative to Competitors Through Customer Satisfaction: A Study of Malaysian Manufacturing Companies. Total Quality Management 11(4-6): 814-819.

Amit R, Schoemaker P. 1993. Strategic Assets and Organizational Rent. Strategic Management Journal 14: 33-46.

Augustyn M, Ho SK. 1998. Service Quality and Tourism. Journal of Travel Research 37(1): 71-75.

Aurioles J, Fernández MC, Manzanera E. 2008. El Distrito Turístico. Mediterráneo Económico 13: 299-326.

Barney JB. 1994. Bringing managers back in: a resource-based analysis of the role of managers in creating and sustaining competitive advantages for firms. In Does Management Matter?: On Competencies and Competitive Advantage, Barney JB, Spender JC, Reve T (eds.). Lund University, Institute of Economic Research: Lund, Sweden; 3-36.
Barney JB, Wright PM. 1998. On Becoming a Strategic Partner: The Role of Human Resources in Gaining Competitive Advantage. Human Resource Management 37(1): 31-47.

Barney JB, Wright M, Ketchen DJ. 2001. The Resource-Based View of the Firm: Ten Years After 1991. Journal of Management 27: 625-641.

Bathelt H, Malmberg A, Maskell P. 2004. Clusters and Knowledge: Local Buzz, Global Pipelines and the Process of Knowledge Creation. Progress in Human Geography 28: 31-56.

Becattini G. 1990. The Marshallian industrial district as a socio-economic notion. In Industrial Districts and Inter-Firm Cooperation in Italy, Pyke F, Becattini G, Sengenberger W (eds). International Institute for Labor Studies: Geneva; 37-51.

Bell GG. 2005. Clusters, Networks, and Firm Innovativeness. Strategic Management Journal 26: 287-295.

Belussi F, Pilotti L. 2002. Knowledge Creation, Learning and Innovation in Italian Industrial Districts. Geografiska Annaler 84(2): 125-139.

Bernstein JI, Nadiri MI. 1989. Research and Development and Intra-Industry Spillovers: An Empirical Application of Dynamic Duality. The Review of Economic Studies 56(2): 249-267.

Brush TH, Bromiley P. 1997. What Does a Small Corporate Effect Mean? A Variance Components Simulation of Corporate and Business Effects. Strategic Management Journal 18(10): 825-835.

Camisón C. 1997. La Competitividad de la PYME Industrial Española: Estrategia y Competencias Distintivas. Civitas: Madrid.

Camisón C. 2001. La Competitividad de la Empresa Industrial de la Comunidad Valenciana: Análisis del Efecto del Atractivo del Entorno, los Distritos Industriales y las Estrategias Empresariales. Tirant lo Blanch: Valencia.

Camisón C. 2002. Las competencias distintivas basadas en activos intangibles. In Nuevas Claves Para la Dirección Estratégica, Morcillo P, Fernández-Aguado J (coords). Editorial Ariel: Barcelona; 117-151.

Camisón C. 2004. Shared, Competitive and Comparative Advantages: A Competence-Based View of Industrial-District Competitiveness. Environment and Planning A 36(12): 2227-2256.

Camisón C, Forés B. 2011. La Competitividad de la Empresa Turística Española: Efectos Empresa, Entorno y Destino. Papeles de Economía Española 128: 238-253.

Camisón C, Monfort V. 2012. Measuring Innovation in Tourism from the Schumpeterian and the Dynamic-Capabilities Perspectives. Tourism Management 33: 776-789.

Camisón C, Monfort VM (dirs.). 2012. La Empresa Turística Familiar en España: Importancia, Perfil y Competitividad. Ministerio de Industria, Energía y Turismo (Estudios del IET): Madrid.

Canina L, Enz CA, Harrison JS. 2005. Agglomeration Effects and Strategic Orientations: Evidence from the US Lodging Industry. Academy of Management Journal 48(4): 565-581.

Castanias RP, Helfat CE. 2001. The Managerial Rents Model: Theory and Empirical Analysis. Journal of Management 27(6): 661-678.

Carbonara N. 2004. Innovation Processes Within Geographical Clusters: A Cognitive Approach. Technovation 24: 17-28.

Cohen J, Cohen P, West SG, Aiken LS. 2003. Applied Multiple Regression/Correlation Analysis for the Behavioral Sciences. 3rd edition. Lawrence Erlbaum Associates: Mahwah, NJ.

Cohen WM, Levinthal DA. 1990. Absorptive Capability: A New Perspective on Learning and Innovation. Administrative Science Quarterly 35(1): 128-152.

Collis DJ. 1991. A Resource-Based Analysis of Global Competition: The Case of Bearings Industry. Strategic Management Journal 12: 49-68.

Conner K. 1991. Theory of the Firm: Firm Resources and Other Economic Theories. Journal of Management 17: 121-154.

Crouch GI, Ritchie JRB. 1999. Tourism, Competitiveness, and Societal Prosperity. Journal of Business Research 44: 137-152.

Dillman DA. 1978. Mail and Telephone Surveys: The Total Design Method. John Wiley \& Sons: New York. 
Dosi G. 1988. Sources, Procedures, and Microeconomic Effects of Innovation. Journal of Economic Literature 26(September): $1120-1171$.

Dwyer L, Edwards D, Mistilis N, Roman C, Scott N. 2009. Destination and Enterprise Management for a Tourism Future. Tourism Management 30: 63-74.

Eisenhardt KM, Martin JA. 2000. Dynamic Capabilities: What are They?. Strategic Management Journal 21(10-11): 1105-1121.

Eldridge S, Balubaif M, Barber KD. 2006. Using a Knowledge Management Approach to Support Quality Costing. International Journal of Quality \& Reliability Management 23(1): 81-101.

Enright MJ, Newton J. 2004. Tourism Destination Competitiveness: A Quantitative Approach. Tourism Management 25(6): 777-788.

Erkus-Öztürk H. 2009. The Role of Cluster Types and Firm Size in Designing the Level of Network Relations: The Experience of the Antalya Tourism Region. Tourism Management 30: 589-597.

Fernández MC, Manzanera E, Aurioles J. 2008. Los Distritos Turísticos en España. International Conference on Measuring Tourism Economic Contribution at sub-national levels, Málaga, Spain, 29-31 October 2008.

Foss NJ, Koch CA. 1996. Opportunism, Organizational Economics, and the Network Approach. Scandinavian Journal of Management 12: 189-205.

Glasmeier A. 1991. Technological Discontinuities and Flexible Production Networks: The Case of Switzerland and the World Watch Industry. Research Policy 20: 469-485.

Goll I, Brown Johnson N, Rasheed AA. 2007. Knowledge Capability, Strategic Change, and Firm Performance: The Moderating Role of the Environment. Management Decision 45(2): 161-179.

Gomezelj D, Mihalič T. 2008. Destination Competitiveness-Applying Different Models, the Case of Slovenia. Tourism Management 29(2): 294-307.

Grant RM. 1991a. Contemporary Strategy Analysis: Concepts, Techniques, Applications. Blackwell Publishers: Cambridge.

Grant RM. 1991b. The Resource-Based Theory of Competitive Advantages: Implications for Strategy Formulation. California Management Review 33(3): 114-135.

Gursoy D, Swanger N. 2007. Performance-Enhancing Internal Strategic Factors and Competencies: Impacts on Financial Success. Hospitality Management 26: 213-227.

Hair JF, Anderson RE, Tatham RL, Black WC. 1998. Multivariate Data Analysis, 5th. Prentice Hall: Englewood Cliffs.

Hall CM. 2005. Rural wine and food tourism cluster network development. In Rural Tourism and Sustainable Business, Hall D, Kirkpatrick I, Mitchell M (eds). Clevendon, Chanel View; 149-164.

Hambrick DC, Cho TS, Chen MJ. 1996. The Influence of top Management Team Heterogeneity on Firms Competitive Moves. Administrative Science Quarterly 41: 659-684.

Hamel M, Heene A. 1994. Competence-Based Competition. Wiley: New York.

Hansen G, Wernerfelt B. 1989. Determinants of Firm Performance: The Relative Importance of Economic and Organizational Factors. Strategic Management Journal 10: 399-411.

Harrison B. 1992. Industrial Districts: Old Wine in New Bottles? Regional Studies 26(5): 469-483.

Henderson R, Cockburn I. 1996. Scale, Scope and Spillover: The Determinants of Research Productivity in the Drug Discovery. RAND Journal of Economics 27(11): 32-59.

Hill CW, Deeds DL. 1996. The Importance of Industry Structure for the Determination of Firm Profitability: A Neo-Austrian Perspective. Journal of Management Studies 33(4): 429-451.

Hjalager AM. 2002. Repairing Innovation Defectiveness in Tourism. Tourism Management 23: 465-474.

Hooley GJ, Greenley GE, Cadogan JW, Fahy J. 2005. The Performance Impact of Marketing Resources. Journal of Business Research 58(1): 18-27.

Howells J. 2004. Innovation, Consumption and Services: Encapsulation and the Combinatorial Role of Services. Service Industries Journal 24(1): 19-36.

Hunt SD, Morgan RM. 1995. The Comparative Advantage Theory of Competition. Journal of Marketing 59(2): 1-15.
Kalnins A, Chung W. 2004. Resource-Seeking Agglomeration: A Study of Market Entry in the Lodging Industry. Strategic Management Journal 25: 689-699.

Koufteros XA, Vonderembse MA, Doll WJ. 2002. Integrated Product Development Practices and Competitive Capabilities: The Effects of Uncertainty, Equivocality, and Platform Strategy. Journal of Operations Management 20(4): 331-355.

Lado AA, Wilson MC. 1994. Human Resource Systems and Sustained Competitive Advantage: A Competency-Based Perspective. Academy of Management Review 19(4): 699-727.

Lawson B, Samson D. 2001. Developing Innovation Capability in Organisations: A Dynamic Capabilities Approach. International Journal of Innovation Management 5(3): 377-400.

Lazari CG, Kanellopoulos DN. 2007. Total Quality Management in Hotel Restaurants: A Case Study in Greece. Journal of Engineering and Applied Sciences 2(3): 564-571.

Lemmetyinen A, Go FM. 2009. The key Capabilities Required for Managing Tourism Business Networks. Tourism Management 30: $31-40$.

Lim Y, Weaver P. 2014. Customer-Based Brand Equity for a Destination: The Effect of Destination Image on Preference for Products Associated With a Destination Brand. International Journal of Tourism Research 16: 223-231.

Longhi C, Keeble D. 2000. High technology clusters and evolutionary trends in the 1990s. In Keeble D, Wilkinson F (eds). High Technology Clusters, Networking and Collective Learning in Europe. Aldershot: Ashgate; 21-56.

Mahoney JT. 1995. The Management of Resources and the Resource of Management. Journal of Business Research 33(2): 91-101.

Martínez R, Charterina J, Araujo A. 2010. Un Modelo Causal de Competitividad Empresarial Planteado Desde la VBR: Capacidades Directivas, de Innovación, Marketing y Calidad. Investigaciones Europeas de Dirección y Economía de la Empresa 16(2): 1135-2523.

Martínez-Ros E, Orfila-Sintes F. 2009. Innovation Activity in the Hotel Industry. Technovation 29: 632-641.

Maskell P, Malmberg A. 2007. Myopia, Knowledge Development and Cluster Evolution. Journal of Economic Geography 7: 603-618.

Mauri AJ, Michaels MP. 1998. Firm and Industry Effects Within Strategic Management: An Empirical Examination. Strategic Management Journal 19: 211-219.

Michael EJ. 2003. Tourism Micro-Clusters. Tourism Economics 9(2): 133-145.

Molina-Azorin JF, Pereira-Moliner J, Claver-Cortés E. 2010. The Importance of the Firm and Destination Effects to Explain Firm Performance. Tourism Management 31: 22-28.

Molteni M, Sainaghi R. 1997. Il Metamanagement di un Distretto Turistico. Economía \& Management 6: 93-104.

Morrison A, Lynch P, Johns N. 2004. International Tourism Networks. International Journal of Contemporary Hospitality Management 16(3): 197-202.

Murphy P, Pritchard M, Smith B. 2000. The Destination Product and its Impact on Traveler Perceptions. Tourism Management 21(1): 43-54.

Narver JC, Slater SF. 1990. The Effect of a Market Orientation on Business Profitability. Journal of Marketing 54(4): 20-35.

Nelson RR, Winter S. 1982. An Evolutionary Theory of Economic Change. Harvard University Press: Cambridge.

Nordin S. 2003. Tourism Clustering \& Innovation. Paths to Economic Growth \& Development. European Tourism Research Institute: Ostersund, Sweden.

Novelli M, Schmitz B, Spencer T. 2006. Networks, Clusters and Innovation in Tourism: A UK Experience. Tourism Management 27: 1141-1152.

OECD. 2005. Oslo Manual: Guidelines for Collecting and Interpreting Innovation, 3rd Edition. OECD Publications: Paris.

Orfila-Sintes F, Crespí-Cladera R, Martínez-Ros E. 2005. Innovation Activity in the Hotel Industry: Evidence from Balearic Islands. Tourism Management 26(6): 851-865. 
Pardellas XX. 2006. La Competitividad Territorial en el Sector Turístico: Notas Sobre el Debate Conceptual y la Literatura Científica. Análisis Turístico 1: 71-74.

Pavlovich K. 2003. The Evolution and Transformation of a Tourism Destination Network: The Waitomo Caves, New Zeland. Tourism Management 24(2): 203-216.

Podsakoff PM, MacKenzie SB, Lee JJ, Podsakoff NP. 2003. Common Method Biases in Behavioral Research: A Critical Review of the Literature and Recommended Remedies. Journal of Applied Psychology 88(5): 879-903.

Podsakoff PM, Organ DW. 1986. Self-Reports in Organizational Research: Problems and Prospects. Journal of Management 12(4): 531-544.

Porter ME. 1990. The Competitive Advantage of Nations. The Free Press: New York.

Porter ME. 1991. Towards a Dynamic Theory of Strategy. Strategic Management Journal 12: 95-117.

Rao H, Drazin R. 2002. Overcoming Resource Constraints on Product Innovation by Recruiting Talent from Rivals: A Study of the Mutual Fund Industry, 1986-1994. Academy of Management Journal 45(3): 491-507.

Reed R, Lemak DJ, Montgomery JC. 1996. Beyond Process: TQM Content and Firm Performance. Academy of Management Review 12(1): 173-202.

Rodríguez-Díaz M, Espino-Rodríguez TF. 2008. A Model of Strategic Evaluation of a Tourism Destination Based on Internal and Relational Capabilities. Journal of Travel Research 46: 368-380.

Rothaermel FT. 2001. Complementary Assets, Strategic Alliances, and the Incumbent's Advantage: An Empirical Study of Industry and Firm Effects in the Biopharmaceutical Industry. Research Policy 30(8): 1235-1251.

Rumelt RP. 1984. Toward a strategic theory of the firm. In Competitive Strategic Management, Lamb E (ed.). Prentice-Hall: Englewood Cliffs; 556-570.

Rumelt RP. 1991. How Much Does Industry Matter?. Strategic Management Journal 12: 167-185.

Sainaghi R. 2006. From Contents to Processes: Versus a Dynamic Destination Management Model (DDMM). Tourism Management 27(5): 1053-1063.

Saxena G. 2005. Relationships, Networks and the Learning Regions: Case Evidence from the Peak District National Park. Tourism Management 26: 277-289.

Schianetz K, Kavanagh L, Lockington D. 2007. The Learning Tourism Destination: The Potential of a Learning Organization Approach for Improving the Sustainability of Tourism Destinations. Tourism Management 28: 1485-1496.

Schmalensee R. 1985. Do Markets Differ Much?. American Economic Review 75: 341-351.

Siemsen E, Roth A, Oliveira P. 2010. Common Method Bias in Regression Models With Linear, Quadratic, and Interaction Effects. Organizational Research Methods 13(3): 456-476.
Smith SLJ. 1994. The Tourist Product. Annals of Tourism Research 21(3): 582-595.

Sorensen JB, Stuart TE. 2000. Age, Obsolescence, and Organizational Innovation. Administrative Science Quarterly 45(1): $81-112$.

Spanos YE, Zaralis G, Lioukas S. 2004. Strategy and Industry Effects on Profitability: Evidence from Greece. Strategic Management Journal 25(2): 139-165.

Srivastava RK, Fahey L, Christensen HK. 2001. The ResourceBased View and Marketing: The Role of Marketing Based Assets in Gaining Competitive Advantage. Journal of Management 27: 777-802.

Sundbo J, Orfila-Sintes F, Sørensen F. 2007. The Innovative Behaviour of Tourism Firms-Comparative Studies of Denmark and Spain. Research Policy 36: 88-106.

Tatikonda MV, Montoya-Weiss MM. 2001. Integrating Operations and Marketing Perspectives of Product Innovation: The Influence of Organizational Process Factors and Capabilities on Development Performance. Management Science 47(1): 151-72.

Teece DJ, Pisano G, Shuen A.1997. Dynamic Capabilities and Strategic Management. Strategic Management Journal 18(7): 509-533.

Teece DJ, Rumelt R, Dosi G, Winter S. 1994. Understanding Corporate Coherence. Theory and Evidence. Journal of Economic Behaviour and Organization 23: 1-30.

Tinsley R, Lynch P. 2001. Small Tourism Business Networks and Destination Development. International Journal of Hospitality Management 20: 367-378.

Tsai KH, Wang JC. 2009. External Technology Sourcing and Innovation Performance in LMT Sectors: An Analysis Based on the Taiwanese Technological Innovation Survey. Research Policy 38(3): 518-526.

Vogt A, Fesenmaier D. 1995.Tourist and Retailer's Perceptions of Services. Annals of Tourism Research 22(4): 763-780.

Wang CH, Chen KY, Chen SC. 2012. Total Quality Management, Market Orientation and Hotel Performance: The Moderating Effects of External Environmental Factors. International Journal of Hospitality Management 31: 119-129.

Weiermair K, Peters M. 2002. Innovation behavior in hospitality and tourism: problems and prospects. In Tourism in Asia: Development, Marketing and Sustainability. Fifth Biennial Conference. Hong Kong Polytechnic University: Hong Kong.

Zaheer A, Bell G. 2005. Benefiting from Network Position: Firm Capabilities, Structural Holes, and Performance. Strategic Management Journal 26(9): 809-825.

Zahra SA, George G. 2002. Absorptive Capacity: A Review, Reconceptualization, and Extension. Academy of Management Review 27(2): 185-203.

Zhou KZ, Wu F. 2010.Technological Capability, Strategic Flexibility, and Product Innovation. Strategic Management Journal 31: $547-561$. 